\title{
THE Profits OF INFRINGEMENT: RICHARD POSNER V. LEARNED HAND
}

\author{
By Stephen E. Margolist
}

\section{TABle of CONTENTS}

I. INTRODUCTION

II. COST CATEGORIES AND WHY THEY MATTER …...................1524

III. LAW AND ECONOMICS I: STATUTES AND PRINCIPLES ….....1527
A. COPYRIGHT
B. TRADEMARK
C. WHY PROFITS?
D. PROFITS UNDER FULL ABSORPTION AND INCREMENTAL COST RULES

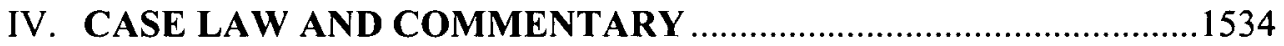

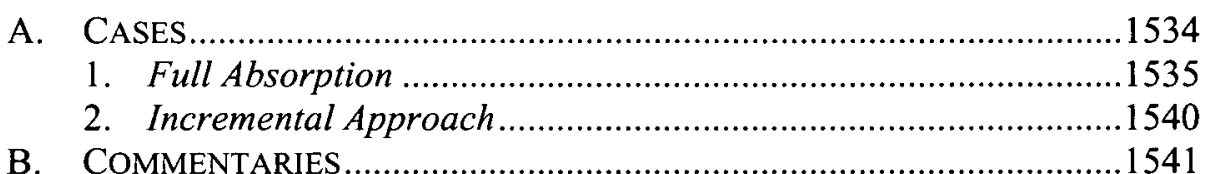

V. OPPORTUNITY COST, ACCOUNTING COST, AND CAPACITY

A. INCREMENTAL OPPORTUNITY COST ..............................................1543

B. AN ECONOMIC DEFENSE OF AN ACCOUNTING PRACTICE .................1545

C. RECONCILING FULL ABSORPTION WITH MANAGEMENT

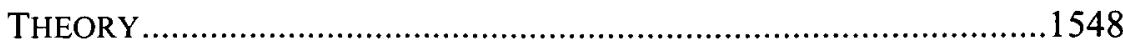

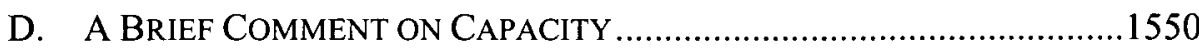

(C) 2008 Stephen E. Margolis.

$\dagger$ Professor of Economics, North Carolina State University. This research was initiated during my sabbatical visit to George Mason University School of Law during the spring term of 2005. I thank the faculty and staff at GMU for their hospitality and collegiality. Thanks also to Stan Liebowitz, Charles Knoeber, Tom Grennes, David Flath, Mark Walker, Bob Peace, Charles Joyner, David Bennett, Anthony Biller, Bruce Kobayashi, Craig Newmark, and Emily Margolis for their comments and suggestions. Thanks also to the participants at the economics workshop at Wake Forest University and the Applied Micro and Industrial Organization Workshop at North Carolina State University. Finally, I acknowledge support for this research from The Center for the Analysis of Property Rights and Innovation at the University of Texas at Dallas. 
E. CaSE LaW: ANOTHER LOOK

VI. LAW AND ECONOMICS II: SHELDON AS AN INCREMENTAL OPPORTUNITY COST RULE

A. WHAT DOES SHELDON DO?

B. RUSS BERRIE'S SENSE OF STYLE: RECONCILING SHELDON WITH THE EXCLUSION OF SOME OPPORTUNITY COSTS

C. EXCEPTIONS

VII. CONCLUSION

\section{INTRODUCTION}

As critics consider strengthening or weakening copyright, the focus has been on the duration and scope of copyright protection, while the remedies available to owners of infringed copyrights receive little attention. Arguably, however, the right is in the remedy. If infringement warranted only a slap on the wrist, copyright protection would offer little benefit to authors and could hardly constitute the impediment to progress that some critics allege. Alternatively, if owners of infringed copyrights are made into life's lottery winners, then producers of creative works will give owners of existing copyrights very wide berths.

Litigation concerning trademark and copyright infringement typically involves calculations of the monetary awards available under the associated statutes. Yet a basic issue concerning how these awards are calculated remains unresolved. The federal courts of appeals do not agree on how awards in these cases should be computed. Even within circuits, district courts sometimes differ on the rules that can determine an infringer's monetary liability. The different rules can lead to order-of-magnitude differences in liability.

Both copyright and trademark law provide remedies that allow a successful plaintiff to capture the defendant's profits from an infringement in addition to damages and other remedies. However, neither statute elaborates on the definition of profits, except to allocate burdens of proof regarding revenues and expenses. In particular, neither statute says anything about which expenses are to be deducted from revenues to obtain an accounting of profits.

Though case law has filled this definitional gap, the courts of appeals still disagree about which costs are deductible. The disagreements concern fixed costs. Some courts apply what is called a full absorption rule, which allows defendants to deduct an allocation of fixed costs. Other courts apply an incremental rule, which does not allow deduction of fixed costs. 
This Article considers economic explanations and legal foundations for the two distinct rules that are present in the case law of copyright and trademark infringement. I will argue that the full absorption rule, as developed in the Second Circuit, particularly by Judge Learned Hand, ${ }^{1}$ comes closer to providing a measure of economic profits than the incremental rule, as applied in the Seventh Circuit and articulated particularly by Judge Richard Posner. ${ }^{2}$ The Article does not propose a new or different rule, but instead shows that elementary economic principles are consistent with the rule that Judge Hand presented in Sheldon, ${ }^{3}$ a rule that may otherwise seem to contradict standard economic teachings.

The next Part addresses cost concepts in two ways: first, by providing the conventional terminology and concepts of cost that are used in economics and accounting and second, by providing empirical evidence that the choice of legal rules is important. Part III provides the foundations in law and economics for this discussion, first considering the copyright and trademark statutes in detail, then applying some simple economic reasoning to illuminate the alternative rules. Part IV documents the appearance of each of the alternative rules, both in appellate case law and in legal commentaries. Part $\mathrm{V}$ makes the case that economic reasoning supports the full absorption rule. I argue that this rule offers a defensible approximation for the incremental opportunity cost of the infringing activity, which is the correct economic concept of cost for the purpose of determining the profits of infringement. Some approximation, rather than exact measurement, is inevitable because accounting information does not capture directly the values of alternative opportunities displaced by the infringement. Part VI returns to the case law, discussing how the full absorption rule as articulated in Sheldon actually works, given accounting practices, to capture an appropriate measure of profits.

1. Sheldon v. Metro-Goldwyn Pictures Corp. (Sheldon I), 106 F.2d 45 (2d Cir. 1939), aff'd, 309 U.S. 390 (1940). For an example of inconsistent application of these rules within a circuit, compare Hamil Am., Inc. v. SGS Studio, Inc., 1998 WL 19991 (S.D.N.Y. Jan. 21, 1998) with Hamil Am., Inc. v. GFI, 193 F.3d 92 (2d Cir. 1999). The district court applied the incremental rule, departing from Sheldon. The Court of Appeals for the Second Circuit reversed and reaffirmed that Sheldon establishes the rule for the circuit.

2. Taylor v. Meirick, 712 F.2d 1112 (7th Cir. 1983).

3. Unless otherwise indicated, all references to Sheldon in the text refer to Sheldon $I$. 


\section{COST CATEGORIES AND WHY THEY MATTER}

Direct costs are the costs of materials and labor that are intimately associated with production of a unit of output. For example, for a hamburger restaurant, the cost of the beef patty, the bun, the pickle, and the wages of the cook would all constitute direct costs. Businesses also have various kinds of indirect costs, which are also called overhead costs. Some overhead costs do vary with the level of activity in the business. In our restaurant example, the wages of the waiters, the bus boys, the dishwashers, and the cashiers would be examples of such costs. Accountants call these variable overheads. Economists group together both direct costs and variable overheads, referring to them as variable costs. Finally, there are indirect costs that may be deemed fixed with respect to output, at least under some restricting assumptions. ${ }^{4}$ In our restaurant example, such costs are associated with the restaurant manager, the building, and the menus. Economists call such costs fixed costs; accountants call them fixed overheads.

Courts that apply a full absorption rule allow defendants to deduct an "appropriate" share 5 of the firm's overhead. Application of this rule results in what is sometimes called "fully allocated costs." In this context, the distinction between fixed and variable overhead is of no consequence since both types are deductible. In contrast, courts that apply an incremental rule disallow deductions for some or all overhead costs. The logic of the incremental rule ${ }^{6}$ dictates that variable overheads, a component of what economists call variable costs, should be allowed, and that fixed overheads (fixed costs) should be disallowed. However, in practice courts sometimes lump together and treat both types of overhead--fixed and variable-as if they are the same and disallow both under an incremental rule.

On the face of it, the incremental rule seems to embody the language and logic of economics. But I will argue that the incremental rule, as implemented, excludes relevant economic costs from the profits calculation. In contrast, the full absorption rule incorporates a defensible proxy for the

4. Such things are conveniently called fixed costs, but that label requires some restriction about the decision horizon. These costs are not fixed for the restaurant operator who today is planning a restaurant that will open next year.

5. What is "appropriate" is not entirely straightforward. Typically, courts that allow a deduction for overheads allow the defendant to allocate overheads in proportion to revenues. For example, if infringing sales constitute ten percent of the firm's sales, the firm is permitted to allocate ten percent of its total overhead to the infringing activity. For more, see infra Section IV.A.1.

6. See infra Section IV.A.2. However, the economic principle is that the benefits of an action are the incremental benefits of the action, less the incremental costs. Clearly, deduction of additional overhead expenses that result from an infringement is consistent with this principle. 
infringer's opportunity costs of using fixed factors in the infringing activities.

The way we count these costs is no mere quibble. Overheads-fixed and variable - are often a large share of a firm's total cost and typically are many times larger than a firm's net income. Consequently, a rule that prevents an infringer from deducting overheads can increase his liability for an infringing activity severalfold.

Let's look at the scale of what is at stake. A firm's income statement typically reports the costs that the firm regards as its direct costs under costs of goods sold. ${ }^{7}$ All other costs are reported under expenses, and for legal proceedings and many other purposes, these expenses are usually called overheads. Revenue minus costs of goods sold is called gross profit; revenue minus costs of goods sold and expenses is called net operating income. It is not at all unusual for a firm to have a very substantial gross profit but a negligible, or even negative, net operating income. For example, it would not be unusual for a firm to show gross profits of 60 or $70 \%$ of sales revenue, but a net operating income of only 5 or $6 \%$. Analogously, an infringer might easily show profits of infringement equal to 5 or $6 \%$ of infringing sales if all overheads were deductible, versus 60 or $70 \%$ of infringing sales if no deduction of overheads were permitted.

Aggregate IRS data on corporate income and expenses provide some corroboration of these claims. IRS data for 2002 for all firms that are classified in manufacturing (NAICS Sector $31-33)^{8}$ show that total receipts less the costs of goods sold is $36 \%$ of total receipts. ${ }^{9}$ For manufacturing firms, accounting practices typically locate all of the direct materials and labor costs in costs of goods sold. Remaining costs are called deductions on a tax return ${ }^{10}$ and are sometimes called overheads in other (non-tax ac-

7. Or costs of sales. Costs of goods sold on statements of operations are not generally identical to direct costs. In manufacturing, for example, costs of goods sold typically includes allocated factory overheads.

8. Office of Mgmt. \& Budget, Executive Office of the President, North AMERICAN INDUSTRY CLASSIFICATION SYSTEM (2002). This system categorizes economic activities into industries. The NAICS codes replace the more familiar Standard Industrial Classification (SIC) codes.

9. Internal Revenue SERvice, 2002 Returns of Active CoRPorations tbl.6 (2002), available at http://www.irs.gov/pub/irs-soi/02co06nr.xls. The figure of $36 \%$ of total receipts is obtained as follows: (Total receipts $(5,257,106,442)-$ Costs of goods sold $(3,353,642,529))$ / Total receipts $(5,257,106,442)$.

10. Tax accounting and cost or managerial accounting are distinct practices, and the terms direct cost and overhead have no exact counterpart in the grouping that shows up in a tax return. In manufacturing, costs of goods sold will often capture almost all that can be associated with the factory floor. This typically will include direct materials and direct 
counting) contexts. Regardless of terminology, this margin-a gross profit - gives a rough indication of the magnitude of profits that a court might award if it disallows any deduction of overheads in determining an infringer's "profits."

In contrast, in the same IRS data, total receipts less total deductions is approximately $1.5 \%$ of total receipts. ${ }^{11}$ This is a margin on all costs, or net operating income, which of course includes all overheads. The twentyfour-fold difference between these two margins, $36 \%$ and $1.5 \%$, offers a very rough idea about the stakes involved in a court's decision regarding whether to allow the infringer to deduct overheads as a cost of the infringing production.

Why do the IRS data offer only a very rough idea? First, the IRS data for manufacturing reflect a massive aggregation - the sums of tax return entries for all corporations classified as manufacturing. ${ }^{12}$ Individual firms will differ enormously. Second, the costs of goods sold may imbed some fixed costs. ${ }^{13}$ In litigation, a plaintiff's economics expert may attempt to identify components of costs of goods sold that are fixed and claim, accordingly, that these costs should be excluded from the costs of infringement.

labor. It may also include an allocation of plant costs, which for other purposes may be treated as fixed costs or overheads by economists and accountants.

11. See INTERNAL REVENUE SERVICE, supra note 9 . The figure of $1.5 \%$ of total receipts is obtained as follows: (Total receipts $(5,257,106,442)$ - Total deductions $(5,178,748,932))$ / Total receipts $(5,257,106,442)$.

12. One might raise a concern that while the IRS data for manufacturing reflects much of the caseload in manufacturing industries, it does not reflect copyright industries as well. To find information on copyright infringers, we might more appropriately look to the information sector (NAICS Sector 51), which includes many of the industries in which copyright is particularly important: newspaper, periodical, and book publishing, directory publishing, software publishing, broadcasting, sound recording, motion picture and video production, news syndicates, libraries and archives, broadcasting, and data processing, among others. Again using the IRS data, for the aggregate of tax returns for corporations in the information sector, the margin on the cost of goods sold (receipts minus costs of goods sold as a percentage of receipts) is $77 \%$ in 2002 . The margin on all costs, including overhead costs, is $-4 \%$ for the same period. Here the difference between an incremental rule and a full absorption rule is more extreme. A firm would show negative profits under a fully allocated cost rule, but owe $77 \%$ of revenues under an incremental cost rule. See INTERNAL REVENUE SERviCE, supra note 9.

13. Furthermore, "book" and "tax" net income are known to differ, with book income often, but not always, exceeding tax income. See GeOrge A. Plesko \& NinA L. SHUMOFSKY, RECONCILING CORPORATION BOOK AND TAX NET INCOME, TAX YEARS 1995-2001, IRS Statistics of INCOME Winter 2004-5 Bulletin, Publication 103. These differences would affect the exact numbers used supra, but not the implication of the order of magnitude in the comparisons shown. 
These caveats aside, it is possible to take the example one step further to see how the alternative rules would play out in litigation, assuming a hypothetical firm with cost and revenue relationships that reflect the IRS data. Suppose an infringing product is $5 \%$ of a firm's sales. Under a rule that allows no deduction of overhead costs, and assuming that gross margins of the firm are, as in the IRS data, $36 \%$ of revenue, the legally determined profits of the infringement would constitute $120 \%$ of the entire net operating income of the firm. ${ }^{14}$

The IRS data and accompanying illustration do not make a case for crediting the infringer for his overheads. An unprofitable firm can undertake a profitable infringement. The point of these illustrations is merely to put the issue into perspective, to show that the choice of rules, though perhaps obscure, is not trivial.

There are several advantages to settling this issue. First, the unsettled nature of the courts' treatment exposes commercial activity to additional risk. Second, it makes litigation outcomes more uncertain, thus reducing the likelihood of settlement. ${ }^{15}$ Finally, if one of these rules is correct, then the continued use of the other in some courts results in either too much litigation or too little, and too much precaution against infringement or too little. If, for example, the courts were to decide systematically to credit overhead, awards to successful plaintiffs would be much smaller, which would reduce both the incentive to litigate and the incentive to take precautions against infringement.

\section{LAW AND ECONOMICS I: STATUTES AND PRINCIPLES}

This Part provides foundations in both law and economics, first presenting the relevant sections of the copyright and trademark statutes, then exploring two economic matters - the rationale for a profits remedy and the actual workings of the two legal rules in the context of a multi-product firm.

\section{A. Copyright}

The Copyright Act of 1976 specifies that the owner of an infringed copyright "is entitled to recover the actual damages suffered by him or her

14. See INTERnAl ReVEnUE SERVICE, supra note 9. In manufacturing (NAICS Sector $31-33$ ), firms earned gross margins of $36 \%$. An award of $36 \%$ applied to $5 \%$ of total revenues would be $1.8 \%$ of total revenues $\left(.05^{*} .36=.018\right)$. Because the firm's net operating income is $1.5 \%$ of its total revenues, as in the IRS data, the award would constitute $120 \%$ of the firm's net operating income $(1.8 / 1.5=1.2)$.

15. George L. Priest \& Benjamin Klein, The Selection of Disputes for Litigation, 13 J. LEGAL STUD. 1, 16 (1984). 
as a result of the infringement and any profits of the infringer that are attributable to the infringement and are not taken into account in computing the actual damages. " As an alternative, the plaintiff can elect to receive statutory damages of up to $\$ 30,000$ "as the court considers just." ${ }^{, 17}$ Further, in cases where infringement is determined to be willful, the court can award statutory damages of up to $\$ 150,000$ per infringement. ${ }^{18}$ In instances where the infringer can prove that he "was not aware and had no reason to believe that his or her acts constituted an infringement of copyright, the court in its discretion may reduce the award of statutory damages to a sum of not less than $\$ 200$.,"19

The statute does not define profits. The only instruction it provides regarding computation of profits is this: "[i]n establishing the infringer's profits, the copyright owner is required to present proof only of the infringer's gross revenue, and the infringer is required to prove his or her deductible expenses and the elements of profit attributable to factors other than the copyrighted work." 20

The availability of statutory damages, over which judges have discretion, assures that the available remedies provide some deterrence and some incentive for litigation even in instances where damages are absent or difficult to establish and profits are absent or very small. Where infringement is willful, greater discretion regarding statutory damages introduces a punitive element. ${ }^{21}$ But the availability of statutory damages does not entirely decouple awards from actual damages and infringer's profits. In important instances, the infringer's profits will exceed the limits on statutory damages. Furthermore, where infringement has not been found to be willful, courts sometimes will scale statutory damages with reference to actual damages and infringer's profits. ${ }^{22}$

16. 17 U.S.C. $\S 504$ (b) (2000).

17. 17 U.S.C. $\S 504$ (c) (Supp. IV 2004).

18. $I d$.

19. Id.

20. $I d$.

21. Id. Willfulness has a particular meaning in this context, requiring more than merely conscious copying, but instead that the infringer was aware that the copying was an infringement or acted in reckless disregard of the possibility that it was. See Fitzgerald Publ'g Co. v. Baylor Publ'g Co., 807 F.2d 1110, 1115 (2d Cir. 1986), cited in Hamil Am., Inc. v. GFI, 193 F.3d 92, 97 (2d Cir. 1999).

22. See Boz Scaggs Music v. KND Corp., 491 F. Supp. 908, 914-15 (D. Conn. 1980 ) (linking statutory damages to information on defendant's gains from infringement); cf. Yurman Design, Inc. v. Paj, Inc., 262 F.3d 101, 113 (2d Cir. 2001) (rejecting the defendant's claim that the statutory damages found should bear some relationship to profits on the grounds that the infringement was willful). 
A related consideration, known as apportionment, is readily distinguishable from the problem of overheads that is the focus of this Article. I mention it here solely to avoid possible confusion. The statute allows the infringer to claim credit for "elements of profit attributable to factors other than the copyrighted work." 23 Such factors may, of course, include other intellectual property. That is, the defendant can apportion the profit among various contributing elements. The standard example is a music album containing twelve songs, where only one of them infringes. If these other songs were understood to be equally important to the profitability of the entire album, the owner of the infringed copyright would be entitled to only one-twelfth of the profits. ${ }^{24}$

\section{B. Trademark}

The recovery provisions of the Trademark Act of 1946 (Lanham Act) read in part:

[T] he plaintiff ... shall be entitled ... to recover (1) defendant's profits, (2) any damages sustained by the plaintiff, and (3) the costs of the action. The court shall assess such damages and profits or cause the same to be assessed under its direction. In assessing profits the plaintiff shall be required to prove defendant's sales only; defendant must prove all elements of cost or deduction claimed. ${ }^{25}$

These provisions closely parallel the recovery provisions of the Copyright Act. Under either Act, the plaintiff can recover damages and the defendant's profits. There are, however, differences. The recovery provisions of the Lanham Act give the court somewhat greater discretion. Under that Act, where the court finds that the recovery based on profits is either inadequate or excessive, it can award any amount that it finds "to be just, according to the circumstances of the case. ${ }^{, 26}$ The court also has discretion to award up to three times the actual damages. The award arrived at

23. 17 U.S.C. $\S 504(b)$ (2000).

24. For an example of such a consideration, see ABKCO Music, Inc. v. Harrisongs Music, 508 F. Supp. 798, 801 (S.D.N.Y. 1981). There were several dimensions to the apportionment. The standard mechanical rights royalty rates would have provided a proportionate allocation of those revenues. However, the court accepted an argument that the infringed song contributed a disproportionately large share to the album's popularity and allocated revenues accordingly.

25. 15 U.S.C. $\$ 1117$ (a) (Supp. IV 2004).

26. Id. 
through these measures "shall constitute compensation and not a penalty."27

Punitive measures are nevertheless available. The Act provides for treble damages "unless the court finds extenuating circumstances" for intentional use of a registered trademark or designation. ${ }^{28}$ Like the Copyright Act, the Lanham Act provides for statutory damages. The owner of a registered trademark can elect statutory damages of up to $\$ 100,000$ per type of good sold, as the court considers just, or up to $\$ 1,000,000$ where the infringement is found to be willful. ${ }^{29}$

\section{Why Profits?}

One could make a pretty good case for ignoring this question. After all, the statutes clearly allow the plaintiff to claim the infringer's profits. With that, the question of what the defendant gained from the infringing act stands on its own. The task left to the economist is to inform the investigation of what the defendant has gained.

Nevertheless, there is an economic question. If there is no foundation for profits as a remedy, we can not expect to gain much from getting profits right. Further, in many areas of the law, damages to the plaintiff, rather than profits of the defendant, are deemed to be the efficient remedy. Specifically, in contract and in many tort claims, including patent infringement, damages suffice. Why should copyright and trademark be different? An interest in economic efficiency favors damages remedies because they prompt efficient precautions against the potential harm. Remedies that are more generous to victims will induce potential tortfeasors to take incremental precautions that have costs that are greater than the expected harm, where expected harm is the damage done multiplied by the probability that the harm occurs. Such precautions are inefficient; they cost more than they are worth.

A difference between copyright and trademark infringement on the one hand and some other torts, including patent infringement, on the other is that copyright and trademark infringement are typically, at least to a degree, deliberate acts. In most cases, copyright infringement requires an act of actual copying - something that is unlikely to occur by accident. Trademark infringement often involves actual copying, and even when it does not, it is readily avoided where trademarks are registered. In both situa-

27. $I d$.

28. 15 U.S.C. $\S 1117$ (b) (Supp. IV 2004). The statute actually refers to the "use of a counterfeit mark," where a counterfeit mark is defined elsewhere in the statute, as, essentially, a counterfeit of a mark that is registered with the Patent and Trademark Office.

29. 15 U.S.C. $§ 1117$ (c) (Supp. IV 2004). 
tions, inadvertent infringement is possible, but unlikely. Under these conditions, there need not be much concern for excessive precaution. In such a circumstance, it is efficient to emphasize deterrence as it imposes little cost and avoids the burdens imposed on the legal system to correct such deliberate acts.

But if deterrence offers benefits in excess of the costs it imposes, why stop at profits? Why not have remedies that offer arbitrarily large awards to owners of infringed copyrights and trademarks in order to assure deterrence? A partial answer is that we do. As noted in the sections supra, both statutes include punitive measures that provide remedies in excess of defendant's profits under certain circumstances. But extreme penalties in order to deter are not without costs. A potential for extraordinary awards would make life hazardous for people engaged in activities that might inadvertently intrude on others intellectual property. Inadvertent infringement is not impossible. It is just rare. ${ }^{30}$

\section{Profits under Full Absorption and Incremental Cost Rules}

As mentioned supra in the introduction, court cases and textbook discussions refer to full absorption methods or fully allocated costs, contrasting that with an incremental method or incremental costs. ${ }^{31}$ Fully allocated costs of an activity include all of the direct costs of the activity, plus any other variable costs, plus (and this is the key) an appropriate allocation of the fixed costs of the enterprise in which the activity takes place. In contrast, incremental costs of an activity include only the additional costs that arise as a consequence of the activity. These can be called the variable costs, and in important instances, they are the very same cost items that we would normally identify as variable costs in economic analysis. That is, they are cost items that change readily with the level of output. ${ }^{32}$.

30. Inadvertent infringement can happen. For example, inadvertent copying of music from memory does happen and is actionable. ABKCO Music, Inc. v. Harrisongs Music, Ltd., 944 F.2d 971, 975 (2d Cir. 1991). Other inadvertent infringement can result from misunderstanding or disagreement about whether a work was created as a work for hire, or whether a license agreement covers a particular use. Frank Music Corp. v. MetroGoldwyn-Mayer, Inc., 772 F.2d 505, 511-12 (9th Cir. 1985). An author might create a derivative work with a mistaken understanding that the use is permitted as parody or criticism. Rogers v. Koons, 960 F.2d 301, 309-10 (2d Cir. 1992). A person or firm may make copies under the mistaken belief that the copying constitutes fair use. Princeton Univ. Press v. Mich. Document Servs., 99 F.3d 1381, 1385-87 (6th Cir. 1996).

31. See, e.g., Warner Bros., Inc. v. Gay Toys, Inc., 598 F. Supp. 424, 428 (S.D.N.Y. 1984).

32. In some instances, however, the incremental costs properly include expenditures on fixed costs that are incurred if and only if the activity is undertaken. For example, special tools that are used only to make an infringing item might have costs that do not vary 
The distinction between full absorption and incremental cost becomes important when a definable activity is less than the whole of an enterprise. If, for example, an enterprise came into being for the sole purpose of selling hotdogs on the Fourth of July and then liquidated its assets on July 5th, fully allocated costs and incremental costs would be identical. Profits, under either definition, would equal all of the revenues from hotdog sales, less all of the expenditures, plus any revenues from liquidation. If this hypothetical holiday hotdog vendor were to have infringed the Snoopy's trademark in its short-lived business, choosing a profits definition would not present a problem. But a difficulty arises if the enterprise sells both infringing hotdogs and noninfringing hamburgers. Certain costs can be directly associated with the hotdogs - the hotdogs and buns themselves, the labor involved with cooking the hotdogs, the labor involved with serving them-but other costs are general costs of the enterprise that are not associated uniquely with either of the two products. An example of such a cost would be the rent on the handcart. The cart is not used up or used in its entirety by either product. Expenditure on the handcart also does not change with the sale of either product.

Each of the definitions of cost has some intuitive appeal as a basis for the remedy for infringement. The incremental profit of selling the hotdogs, as opposed to selling only the hamburgers (and thus keeping everything else the same), is the difference between the hotdog revenues and the costs that arise as a consequence of selling the hotdogs - the extra, or incremental, cost of the hotdogs. It is probably safe to say that this is the concept of the cost of the infringement that comes to mind first for economists. It mimics the marginal revenue-marginal cost comparison that is inherent in so much of what economics teaches. ${ }^{33}$ The fixed costs, we would argue, are irrelevant to the choice of the number of hotdogs to sell and further would be irrelevant to the choice of whether to sell hotdogs or not, provided that the hamburger business was already in place.

with the amount of infringing output, but that nevertheless constitute an additional cost that is a consequence of the infringement. Such costs are properly deductible under either rule. This is consistent with the standard definition of incremental costs. See, e.g., SIDNEY Davidson et al., Managerial Accounting: An InTroduction to ConCEPTS, MethODS AND USES 901 (9th ed. 2005), which defines incremental cost as follows: "Incremental costs will be incurred (or saved) if a decision is made to go ahead (or stop) some activity, but not otherwise." On the next page, fully absorbed costs are distinguished from variable costs as follows: "Fully absorbed costs refer to costs where fixed costs have been allocated to units or departments as required by generally accepted accounting principles. Variable costs, in contrast, may be more relevant for making decisions, such as setting prices." Id. at 902.

33. For an extensive discussion of this point, see infra Section V.C. 
Still, many laypersons, accountants, and business people are inclined to account for those other costs. One proffered defense of full cost allocation is that all costs have to be "accounted for somewhere." Even though business people will often be alert to their margins on variable costs, they also want to have some reading on whether a product line is profitable when "fully burdened." 34 After all, if each of the products of a multiproduct firm shows positive margins on variable costs, but the sum of all those margins is inadequate to cover fixed costs, the firm as a whole will be unprofitable, notwithstanding the consistently encouraging news that we get by computing profits on variable costs one product at a time.

A reasonable approach to profit, therefore, is to look at a product as a portion of an enterprise, allocating the costs that cannot be readily associated with individual products in proportion to the share of the business that each product represents. Although the "in proportion" is not uncontroversial, common allocation methods involve allocating fixed costs to individual products in proportion to their shares of direct costs or total revenues.

Economists typically reject such reasoning about cost where the purpose of the cost calculation is to inform a decision about whether to undertake an additional activity or to determine the optimal level of activity. The economic dictum is that the activity is worth undertaking if the incremental gains are greater than the incremental costs, properly defined. Further, the gain from the undertaking (the profit) is the difference between the two. Economists are correct about this, and everyone else is wrong. This, however, is only true when we confine the issue to the tidy problem in which the choice is simple-this activity or nothing - with all incremental costs and benefits readily understood and quantified.

Both the words of the copyright statute and standard teachings of economics would seem to come down on the side of an incremental approach to calculating profits. The statute speaks of "any profits of the infringer that are attributable to the infringement. ${ }^{35}$ The costs that arise as a consequence of infringement- the incremental costs-are the costs that are "attributable to the infringement." The logic of efficient deterrence, as explored supra, also imposes an incremental definition. ${ }^{36}$ The potential infringer will be deterred from infringement if the expected penalty is disgorgement of exactly what he gains from infringement. That gain would be the incremental revenues that he would receive from the infringement,

34. Fully burdened cost is another synonym for fully allocated cost. Allocated fixed cost is sometimes referred to as allocated burden.

35. 17 U.S.C. $\$ 504$ (b) (2000).

36. See supra Section III.C. 
less the incremental costs. A substantial body of economic thought and a substantial portion of instruction in economics make exactly this point.

Unfortunately, however, as is often the case for economic principles, what is very simple and clear in a world of useful but restrictive assumptions becomes complicated when we move to actual practice. For the issue at hand, infringement litigation, the complication arises because of features of real business activities that are difficult or impossible for people outside the business to observe. Much of the burden of the rest of this Article is to establish that while the principle underpinning a correct profits measure is incremental revenues minus incremental costs, economic reasoning offers a compelling argument for using full absorption costs as the basis, or at least the starting point, for determining profits in infringement. At the heart of this argument is proper attention to opportunity cost, the concept of cost that underpins all of economics.

\section{CASE LAW AND COMMENTARY}

Both case law and commentaries by legal scholars have addressed the use of full absorption and incremental methods of determining profits. This Part shows that both methods have clear precedent in case law, and both are reflected, though perhaps less clearly, in expert commentaries.

\section{A. Cases}

In case law on intellectual property infringement, there are actually two splits. First, some circuits allow defendants to allocate a share of their overheads to their costs in computing profits, and some circuits do not. Second, among the circuits that do allow defendants to allocate a share of overhead costs, some deny that credit to defendants whose infringement is willful. The concern of this Article is almost entirely with the first of these splits, though the issue of willfulness will be considered briefly infra. This second split is noted here to avoid potential confusion.

The leading circuit on the side of the incremental method-allowing only variable costs-is the Seventh Circuit. ${ }^{37}$ The leading circuits on the side of full absorption-allowing deduction of fixed and variable overheads - are the Second ${ }^{38}$ and Ninth ${ }^{39}$ Circuits. This is an older line of cases than those that support the incremental method, originating in the

37. Taylor v. Meirick, 712 F.2d 1112 (7th Cir. 1983).

38. Sheldon I, 106 F.2d at 45.

39. Kamar Int'l, Inc. v. Russ Berrie \& Co., 752 F.2d 1326 (9th Cir. 1984). 
Second Circuit and surviving review by the Supreme Court. ${ }^{40}$ Full absorption is also favored in the leading copyright treatise, although more recent commentaries suggest that the weight of scholarship, if not legal precedent, favors an incremental approach. ${ }^{41}$

\section{Full Absorption}

In Sheldon v. Metro-Goldwyn Pictures, ${ }^{42}$ the Second Circuit Court of Appeals deals directly with the conflict between an incremental rule and a rule that allows an allocation of overheads: "Next is a challenge [by the plaintiff] to any allowance for 'overhead' at all, on the theory that the defendants did not show that it had been increased by the production of the infringing picture. ${ }^{, 43}$ In response to this challenge, Learned Hand writes what is often called the Sheldon rule: ${ }^{44}$ "“' [o]verhead" which does not assist in the production of the infringement should not be credited to the infringer; that which does, should be; it is a question of fact in all cases." ${ }^{45}$

Hand does not provide his own justification for the rule, but instead relies on Levin Bros. v. Davis Manufacturing, ${ }^{46}$ an Eighth Circuit patent case, saying only, "The correct rule upon this point is stated in Levin $\ldots .,{ }^{47}$ before offering his rule as the substance of Levin. The preamble to Hand's statement of the rule makes it clear that the challenged overheads include fixed costs - that is, those that had not been shown to be "increased by the production of the infringing picture." ${ }^{, 48}$ Thus the costs that can be deducted under the rule are not limited to variable overhead, but also include the costs of fixed assets, such as fixed facilities that can be said to "assist" in the infringing activity.

Assets that would not "assist" would be, for example, those owned by the infringer but involved in an unrelated line of business. Consequently, the Sheldon rule is not a simple full absorption rule because it conditions deductibility on having some relationship to the infringing activity. However, elsewhere Judge Hand cautions that requiring a detailed inquiry into

40. Sheldon v. Metro-Goldwyn Pictures Corp. (Sheldon II), 309 U.S. 390 (1940). See infra text accompanying note 42 .

41. See infra Section IV.B.

42. Sheldon I, 106 F.2d at 45 .

43. Id. at 54.

44. For example, Warner Bros., Inc. v. Gay Toys, Inc., 598 F. Supp. 424 (S.D.N.Y. 1984) refers to the "Sheldon rule." Apparently the "Hand rule" was taken.

45. Sheldon I, 106 F.2d at 54.

46. 72 F.2d 163 (8th Cir. 1934). Prior to the 1952 act, the owner of an infringed patent could be awarded defendant's profits.

47. Sheldon I, 106 F.2d at 54 (citation omitted).

48. Id. 
the involvement of each asset that the firm owns would be an "impossible" endeavor and acknowledges the practical need for allocating cost according to proportionate shares of entire categories of related costs. ${ }^{49}$

Sheldon reached the Supreme Court, ${ }^{50}$ which concerned itself primarily with the issue of apportionment and affirmed the court of appeals. The Supreme Court did not discuss overheads explicitly but did explicitly affirm the lower court's finding of fact on this issue: "Petitioners [plaintiff] also complain of deductions in the computation of the net profits. These contentions involve questions of fact which have been determined below upon the evidence and we find no ground for disturbing the court's conclusions." 51

In Neal v. Thomas Organ Co., ${ }^{52}$ a district court in the Ninth Circuit allows the defendant to deduct overheads, credited as a portion of infringing sales equal to the ratio of overheads to sales for the firm as a whole. The court's support for this action is along the lines of the "all costs must be accounted for somewhere" argument discussed supra. ${ }^{53}$ Without citing any authority, the court states, "[i]t is common knowledge that any business has indirect costs and this per cent should apply in the selling and handling of the [infringing goods] by defendant the same as it would apply in the handling of any other items." 54 (In Neal, the court uses the term "indirect costs" rather than "overheads.") In essence, the court's argument is that overhead should be deducted (or applied) as a cost in calculating the profits of infringement because it is deducted in profit calculations for other purposes.

In Kamar International, Inc. v. Russ Berrie \& $\mathrm{Co}^{55}{ }^{55}$ a frequently cited Ninth Circuit case, the court of appeals offers the justification for allocating overheads in Neal, and then adopts the Sheldon rule. ${ }^{56}$ The Kamar court thus allows a proportionate allocation of overheads but only after

49. Id. at 52. Hand writes:

[T] o make a perfect allocation one would have to examine what part of the time of all the employees whose pay went into the 'overhead' was given to each picture; and so of the other expenses. That was obviously impossible ... . The master's solution [using the cost of production of each picture] appears to us as nearly right as was practically possible.

Id.

50. Sheldon II, 309 U.S. at 390.

51. Id. at 409 .

52. 241 F. Supp. 1020, 1022 (C.D. Cal. 1965).

53. See supra text accompanying note 34 .

54. Neal, 241 F. Supp. at 1022.

55. 752 F.2d 1326 (9th Cir. 1984).

56. Id. at 1332 . 
confronting some of the controversies that are at issue in this Article. That court rejects a lower court position that overheads should be excluded if the infringing sales were only a small percentage of the infringer's total sales:

The real question, as we see it, is whether any of the overhead expenses were caused by the production or sale of the infringing goods, not the proportionate amount of sales of the goods in relation to total sales. Because of the varying situations which may arise and the lack of needed flexibility in an arbitrary standard, we decline to adopt a legal rule disallowing all overhead deductions merely because the sales of the infringing goods constitute a small percentage of total sales. ${ }^{57}$

That statement leans toward an incremental rule. The court leans just a bit further, questioning whether overhead costs should be allowed when they are not caused by the infringement, before offering a further justification for the Sheldon rule:

On the other hand, such [an incremental] rule might create perverse incentives for a copyright owner to delay enforcing his rights and instead allow a diversified infringer to produce and sell infringing goods. If the copyright owner currently uses his fixed overhead to capacity, he would obtain by lawsuit net profits greater than he could have earned. ${ }^{58}$

In effect, absent allocation of the defendant's overheads, the copyright owner would be using the infringer's capacity rent free. The court's argument is different from but closely related to the argument in favor of a full absorption approach presented in this Article.

The Kamar court acknowledges that the Seventh Circuit allows deduction of overheads only if they are increased with the infringing activity and acknowledges that other courts have adopted equivalent rules. It then, however, concludes that the goals of deterrence and compensation "can best be achieved by allowing a deduction for overhead only when the infringer can demonstrate it was of actual assistance in the production, distribution or sale of the infringing product." 59

Kamar was followed shortly in the Ninth Circuit by Frank Music Corp. v. Metro-Goldwyn-Mayer, Inc., ${ }^{60}$ which also adopts the Sheldon

57. Id. (emphasis added).

58. $I d$.

59. Id.

60. 772 F.2d 505 (9th Cir. 1985). 
rule. In Frank, the issue relating to allocation of overheads was evidentiary. The defendant had allocated overheads to various products by cost categories in proportion to revenues, and the district court had approved this method of allocation. The court of appeals found that the lower court's finding was not clearly erroneous and also acknowledged that the practicalities of accounting dictate that overheads will necessarily be addressed in broad categories rather than as individual items. However, the court ruled that the defendant is obligated to demonstrate, "at least in general terms," that the overhead items being allocated "contributed to the production of the infringing work," Sheldon rule. Frank is cited often for several propositions, one of which is this further articulation of the assignment of the burden of proof.

One additional Second Circuit case of note is Hamil America v. GFI, ${ }^{62}$ which explicitly rejects a lower court decision that required the defendant to calculate profits using an incremental approach. Hamil draws on Sheldon in detail, concluding that Sheldon "contemplates a two step procedure for deducting overhead expenses from an infringer's profits." ${ }^{33}$ The steps identify the expense categories that are actually "implicated" in the infringing production, and then develop a "fair, accurate and practical method" of allocating the associated expenses. ${ }^{64}$

Thus we have the Second and Ninth Circuits, as well as some others, ${ }^{65}$ adopting a rule that allocates overhead expenses by category and without regard to whether the expense varies with the level of output. The rule articulated in Sheldon is not exactly full absorption, since expenses in categories that did not "assist in the production of the infringement" cluded from the cost of the infringement. And some courts have wavered in applying Sheldon as an approximate full absorption rule, ${ }^{67}$ interpreting

61. Id. at 516 .

62. 193 F.3d 92 (2d Cir. 1999).

63. Id. at 105 .

64. Id.

65. Including the Sixth Circuit, Schnadig Corp. v. Gaines Mfg. Co., Inc., 620 F.2d 1166 (6th Cir. 1980), and the Eighth Circuit, Levin Bros. v. Davis Mfg., 72 F.2d 163 (8th Cir. 1934).

66. Sheldon I, 106 F.2d at 54.

67. In Banff Ltd. v. Express, Inc., 921 F. Supp. 1065 (S.D.N.Y. 1995), a jury accepted the plaintiffs' experts' calculations, which excluded overheads that were not "sensitive" to output. The court did not rule that the jury's finding was contrary to law, ruling " $[\mathrm{t}]$ he incremental approach is consistent with the Second Circuit's command that 'overhead' which does not assist in the production of the infringement should not be credited to the infringer; that which does, should be." Id. at 1070 (quoting Sheldon I, 106 F.2d at 54). Other courts have also been confused by the language in Sheldon. See, e.g., In re 
"assist in the production" to mean that the expense category must vary with output. In economic terms, this is a clear error, and it is inconsistent with the application in Sheldon and other cases. ${ }^{68} \mathrm{~A}$ productive asset can assist in production without its cost changing. To take a simple example, if a knitting operation occupies space in a factory building, the building can readily be said to "assist," yet the rent on the factory is unaffected by the use of the space. The treatment of the factory expense under Sheldon and an incremental rule are clearly distinct: Sheldon would allocate a portion of the factory expense; an incremental rule, as it is usually stated, would not.

As noted in the introduction to this Part, courts applying either a simple full absorption rule or the Sheldon "actual assistance" rule have sometimes conditioned deduction of overheads on findings regarding willfulness. ${ }^{69}$ Some courts have held that willful infringement precludes an allocation of overheads. ${ }^{70}$ Others have suggested that overheads should receive particularly careful scrutiny where the infringement is willful. For example, in Sheldon, the court held that because the infringement was

Indep. Serv. Orgs. Antitrust Litig., 23 F. Supp. 2d 1242, 1251 (D. Kan. 1998) (decided by a district court in the Tenth Circuit).

68. In Sheldon I, Judge Hand addresses overheads broadly, with no attention to whether production of the infringing motion picture had any effect on expenditures. He specifically addresses "supervising staff and organization, which had to be maintained if the business was to go on at all." Sheldon I, 106 F.2d at 54. Further, he specifically addresses, and allows deductions for, "continuities scrapped" and "completed pictures never exhibited," treating such "breakage" as an inevitable cost of doing business. Id. See also Warner Bros., Inc. v. Gay Toys, Inc., 598 F. Supp. 424, 429 (S.D.N.Y. 1984), in which the court rejects plaintiffs' claim, with discussion and citation, that Sheldon I supports the incremental approach.

69. In copyright, willfulness requires more than just conscious copying. For infringement to be willful, the infringer must have known that the copied article was under copyright and that their action was an infringement. Infringers have been found nonwillful where they clearly copied but had reason to believe that their copying was covered by a license agreement, Frank Music Corp. v. Metro-Goldwyn-Mayer, Inc., 772 F.2d 505, 515 (9th Cir. 1985), or where they believed that their copying fell under fair use, Princeton Univ. Press v. Mich. Document Servs., 99 F.3d 1381, 1392 (6th Cir. 1996). In trademark infringement, any monetary recovery requires either registration of the infringed mark, 15 U.S.C. $\S 1117$ (2000); a misrepresentation or use of any "word, term, name, or device," that is likely to cause confusion, 15 U.S.C. $\$ 1125$ (a) (2000); bad faith, 15 U.S.C. $\S 1125(d)$ (2000); or willful dilution, 15 U.S.C. $\S 1125(c)$ (2000). In short, any monetary recovery requires some awareness, willfulness, or bad faith.

70. See Saxon v. Blann, 968 F.2d. 676, 681 (8th Cir. 1992) ("Overhead may not be deducted from gross revenues to arrive at profits when an infringement was deliberate or willful."). Other courts have set forth a more nuanced rule, giving the court discretion where infringement is willful. See Kamar Int'l, Inc. v. Russ Berrie \& Co., 752 F.2d 1326, 1331 (9th Cir. 1984). 
willful, only "bought and paid for" overhead items could be deducted. ${ }^{71}$ Still other courts reject any link between willfulness and deductibility. In ZZ Top v. Chrysler Corp., the court stated that nothing in the statute supported a rule disallowing deduction of overhead where infringement is willful. ${ }^{72}$ The court notes that because disallowing an overhead deduction would take away more than just profits from the defendant, the defendant would therefore suffer punishment. ${ }^{73}$ Noting that there are explicit punitive measures for willful infringement in the copyright statute ${ }^{74}$, the court refused to incorporate an additional punitive element by adjusting the profits measure.

\section{Incremental Approach}

The key opinion in support of an incremental approach is Taylor $v$. Meirick ${ }^{75}$ a copyright case in the Seventh Circuit. In ruling to disallow credit for certain fixed costs, Judge Richard Posner writes, (referring to the defendant):

His 'gross profits' were real profits in the only sense relevant to damages calculation - they were his residual income after all costs necessary to generate the income were subtracted. Costs that would be incurred anyway [in the absence of the infringement] should not be subtracted [from revenues to obtain defendant's profits] because by definition they cannot be avoided by curtailing the profit-making [infringing] activity. This principle is well established in the treatment of overhead costs in calculating damages for breach of contract. See FARNSWORTH, CONTRACTS 854-55 (1982). ${ }^{76}$

Note that Posner does not cite any copyright or trademark case or any other authority in this ruling. Nevertheless, his ruling is a clear statement of the economic reasoning supporting an incremental rule, and it reflects

71. Sheldon I, 106 F.2d at 51. Overheads that would not be "bought and paid for" presumably include assets of the firm's own creation, like its reputation and know-how. Id. These items are typically accounted for as the firm's "goodwill." Id. Hand's illustration is "the currency which [the plagiarist's] reputation may have given to the combined project." Id.

72. ZZ Top v. Chrysler Corp., 70 F. Supp. 2d 1167, 1168 (W.D. Wash. 1999).

73. Id.

74. Id. ("Where Congress intended to punish willful infringement by authorizing different remedies depending on the infringer's culpability, it clearly knew how to do so. See 17 U.S.C. $\$ 504$ (c) (authorizing a five fold increase in statutory damages if defendant's conduct was willful).").

75. 712 F.2d 1112 (7th Cir. 1983).

76. Id. at 1121 . 
accepted teaching in economics. Indeed, a fundamental teaching in economics is that the gain from an action is the incremental benefit less the incremental cost. This is always true. The hard part in theory is defining cost and benefit correctly. The hard part in practice is observing them.

In a subsequent Seventh Circuit case, Roulo v. Russ Berrie \& Co., the court adopts an incremental rule without comment or citation, specifically adopting a variable-costs-only interpretation: "[The defendant's witness] improperly deducted certain administrative expenses without demonstrating they were variable costs. Fixed costs are not deducted from the profit calculation." 77

Courts within the Tenth Circuit have cited Taylor and Roulo when adopting an explicit incremental rule. ${ }^{78}$ Elsewhere, however, at least one court has explicitly refused to adopt Taylor. ${ }^{79}$

\section{B. Commentaries}

Nimmer ${ }^{80}$ covers overheads only briefly. He does not distinguish between the Sheldon rule, which allows credit for fixed overheads if they contribute to the infringing production, and the Taylor rule, which allows credit only for costs that are increased with the infringing activity. He cites the two-step process in Hamil, noting that the "defendant has the burden of proving that each item of general expense contributed to the production of the infringing items," for this).$^{82}$ As Sheldon notes, requiring that an input "assist[s] in the production of the infringement" is not the same as requiring that an input constitute a cost that would not be incurred in the absence of the infringement (as in the Taylor rule). ${ }^{83}$ The first requirement allows allocation of the costs of fixed factors; the second does not. In Nimmer's discussion, however, the two alternative rules seem to merge. On the other hand, in citing a recent district court ruling in the Second Circuit, Nimmer does report that "[o]ne court favors the full absorption method, which permits the de-

77. 886 F.2d 931,941 (7th Cir. 1989).

78. In re Indep. Serv. Orgs. Antitrust Litig., 23 F. Supp. 2d, 1242, 1251 (D. Kan. 1998).

79. Allen-Myland, Inc. v. IBM Corp., 770 F. Supp. 1014, 1025 (E.D. Pa. 1991).

80. Melville B. Nimmer \& DAVID Nimmer, Nimmer ON COPYRIGHT § 14-03(c) (1977). This is the primary treatise on copyright.

81. Id. at $\S 14-03(\mathrm{c})(3)$.

82. Id. at $\S 14-03(\mathrm{c})(3)$ n. 152.

83. Sheldon I, 106 F.2d 45 at 54; Taylor v. Meirick, 712 F.2d 1112, 1121 (7th Cir. 1983). 
fendant to deduct all overhead expenses in the same percentage as the sales of the infringing goods bears to its total sales." 84

Most commentators do not treat cost issues very thoroughly, but an exception is a paper on monetary relief in trademark by James Koelemay. ${ }^{85} \mathrm{He}$ observes that there is little in the case literature regarding the methods for computing profits or the basis for choosing one method over another. ${ }^{86}$ Koelemay identifies three rules (rather than the two discussed here): a pure incremental rule as in Taylor, an assist-in-production rule as in Sheldon, and a pure full absorption rule. ${ }^{87}$

Koelemay offers support for an incremental rule, which he calls the "differential cost or marginal cost rule" on the basis that it provides the largest awards to plaintiffs and is "consistent with modern business school management theory, which holds that transactions are profitable if they yield a positive contribution to overhead." ${ }^{88} \mathrm{He}$ is correct that management courses, particularly in managerial economics, teach that decisions should be based on a comparison of marginal (or incremental) benefits and marginal costs. The problem is the applicability of this framework to litigation. The thrust of the argument that appears infr ${ }^{89}$ is that the highly conditioned decisions that are considered in managerial economics textbooks, or for that matter are made in actual business decisions, are quite

84. NimmER, supra note 80 , at $§ 14-03$ (c) (citing New Line Cinema Corp. v. Russ Berrie \& Co., 161 F. Supp. 2d 293, 303 (S.D.N.Y. 2001)).

85. James M. Koelemay, Jr., A Practical Guide to Monetary Relief in Trademark Infringement Cases, 85 TRADEMARK REP. 263 (1995).

86. Id. at 287-88.

87. Even adopting Koelemay's three rules, there are still two types of rule: those that allocate some overheads and those that do not. Moreover, Sheldon I and its precursor, Levin Bros. v. Davis Mfg. Co., 72 F.2d 163 (8th Cir. 1934), are cited by most courts that allow any allocation of overhead and are at all explicit about the foundations for that treatment. For example, in Wolfe v. National Lead Co., 272 F.2d 867, 871 (9th Cir. 1959), a case Koelemay cites as a full absorption case, all of the infringer's production was paint production, some of which was infringing, some not, so there really could be no assisting and non-assisting overhead items. See Koelemay, supra note 85, at 289 n.130. The court states no explicit explanation for a full absorption rule, other than a lack of detail in the infringer's records. Wolfe, 272 F.2d at 872. The Ninth Circuit rule appears to be captured in Frank Music Corp. v. Metro-Goldwyn-Mayer, Inc., 772 F.2d 505, 516 (9th Cir. 1985) (citing Sheldon I, 106 F.2d at 54), which explicitly states the assist-inproduction rule. Koelemay also cites Schnadig Corp. v. Gaines Mfg. Co., Inc., 620 F.2d. $1166,1171-75$ (6th Cir. 1980) as applying a full absorption rule. Koelemay, supra note 85 , at 289 n.130. Schnadig allocates only two-thirds of overhead, excluding one third on a basis that echoes the assist-in-production rule. Schnadig, 620 F.2d. at 1175.

88. Koelemay, supra note 85 , at 288.

89. See infra Section V.C. 
different from the consideration of profit that must be undertaken in litigation.

And finally, in a Practicing Law Institute Handbook entry, Crittenden and Pak note that "[p]erhaps the most debated issue of deductibility is whether defendants cannot deduct various types of overhead." 90 Amen.

\section{OPPORTUNITY COST, ACCOUNTING COST, AND CAPACITY}

The introduction to this Article promises to show that elementary economic principles are consistent with the rule presented in Sheldon. This Part takes up that task. First, I present two basic teachings of economics: actions are properly evaluated by comparing incremental benefits with incremental costs, and all costs are opportunity costs. Next, I show that a full absorption rule provides a defensible proxy for opportunity cost, which is a core claim of this Article. I further elaborate on this claim by showing that the evaluation problem presented in management decision-making is different from the evaluation problem presented in litigation, primarily because the information available is unavoidably different. Finally, I offer some comments on capacity constraints and connect these arguments back to arguments that appear in case law.

\section{A. Incremental Opportunity Cost}

The underlying economic principle articulated in Taylor is correct: The profits of infringement are the incremental revenues less the incremental costs. The gain from any action is the incremental benefits of the action less the incremental costs. For most business decision problems, we substitute the firm's revenues for "benefits." This is not a completely innocent substitution, however, since a firm might enjoy additional benefits from infringement, such as enhanced reputation or reduced costs. Those benefits clearly are as legitimate a component of profits as revenues, and indeed if they can be demonstrated satisfactorily and quantified on some reasonable basis, they are properly incorporated in an award of profits.

That leaves us with the problem of cost. In economics, the fundamental concept of cost is opportunity cost. The opportunity cost of any action is the value of things forgone as a result of the action. Opportunity cost follows immediately from the basic economic concept of scarcity. There is

90. John W. Crittenden \& Eugene M. Pak, Monetary Relief Under Lanham Act Section 35, in LITIGATING COPYRIGHT, TRADEMARK AND UNFAIR COMPETITION CASES FOR THE EXPERIENCED PRACTITIONER 393, 412 (1998). 
no cost in economics that is not an opportunity cost. If nothing of value is forgone as a result of some action, that action does not have any cost. ${ }^{91}$

Given the economic definition of cost, the correct incremental rule is this: The profits of an action are the incremental revenues and other benefits, less the incremental opportunity costs, where the incremental opportunity costs are constructed to include all of the increases in explicit costs, plus any additional opportunity costs that are not reflected in the changes in explicit costs. These additional opportunity costs are the values of any actions that are forgone as a result of the chosen action and commonly will be the values of activities that would otherwise occur in fixed facilities or be undertaken by an unchanging supervisory staff. ${ }^{92}$

The problem with implementing this incremental rule arises when economists' concept of incremental opportunity cost encounters accountants' actual data. While incremental profit is what we are after, it will not, in general, be computed correctly by counting as costs only those accounting cost items that can be observed to change with the level of outputthat is, only those accounting cost items that are changed as a result of an infringement.

Consider some simple examples. Suppose an infringement directly uses labor and materials. Each of these will be fully captured in the accounting records as part of the total expenditures for these categories. Suppose that there are no other explicit variable costs that show in the accounting records. Suppose further that the infringing activity uses a wing in a building that houses a number of unrelated activities. Finally, suppose that the building is leased as a whole for a set period of time with no possibility of subleasing any portion of the building. If the infringer has no expected alternative future use for the wing that is used for the infringing

91. Some elementary treatments of the economics of decision-making sometimes treat opportunity cost as a distinct category of cost, as in, there's labor cost, materials costs, rent, phone, insurance, and don't forget opportunity cost. This treatment is incorrect. Each of these items is an opportunity cost. The opportunity cost of one hundred dollars spent on labor is one hundred dollars that cannot be spent on something else. Because the cost of labor occurs as an expenditure, we recognize it as a cost directly without explicitly considering the value forgone. The "special" opportunity costs in the statement are merely the cost items that do not appear as explicit expenditures. But these costs are not differentiated; they are all opportunity costs.

92. There is a general problem that the values of forgone opportunities are often difficult to observe for outsiders, and particularly for outsiders after the fact. The value of the forgone activity is unseen. Nevertheless, economizing decision makers will properly consider these costs. In much of what follows, the concern is with identifying an appropriate proxy for opportunity cost in light of our inability to observe opportunity cost directly. 
activity, then the explicit labor and materials costs capture the full costs of the infringement. But the assumption that there is "no expected alternative future use" is a severe restriction. While firms occasionally do find themselves with excess capacity, it is an error to make excess capacity a default assumption. To do so abandons the more fundamental assumption that firms maximize profits. Why would a firm acquire and maintain capacity that it does not expect to use? Undoubtedly firms do sometimes find themselves with excess capacity, but in those cases we expect that they will make efforts to develop new outlets for their products, find new products, or sell (rent) off their excess capacity. As is elaborated below, we should not expect that firms accept excess capacity for the long term.

Note further that in this instance, the simplified textbook economic model, though useful for establishing important general principles, is misleading. The standard textbook model of the firm typically specifies one product per firm. ${ }^{93}$ Such a model does in fact yield an implication of excess capacity in equilibrium under certain assumed market structures, particularly what is known as monopolistic competition. However, this implication does not survive generalization to multi-product firms, even where such firms have a degree of monopoly power. ${ }^{94}$

As elaborated supra, ${ }^{95}$ there is no conflict between the incremental cost rule and the full absorption rule for a single-product infringer. The conflict between the rules arises only in the case of a multiproduct firm. For contemporary multiproduct firms, managing a regular turnover of product lines is an essential part of business. It is not reasonable to assume that the norm is for firms to be in a condition of chronic excess capacity that is manageable only by an episode of infringement. Yet ignoring the value of alternative uses of fixed facilities is to make precisely that assumption.

\section{B. An Economic Defense of an Accounting Practice}

One might well ask whether the allocated accounting costs of fixed facilities, or unchanging supervisory staff, or any other fixed factor, might

93. Harold Demsetz, Economic, Legal and Political Dimensions of CompeTITION 9-10 (1982).

94. See Stephen E. Margolis, Monopolistic Competition and Multiproduct Brand Names, 62 J. BUS. 199 (1989). That paper shows that when common costs are shared by multiple product lines, the excess capacity implication of the Chamberlin monopolistic competition model does not apply. More simply, where a firm can produce more than one output, if downward-sloping demand limits the firm's output below cost-minimizing levels, it can add either other differentiated goods or generic goods to exploit any unused capacity.

95. See supra Section III.D. 
capture the opportunity costs of their use in infringing production. The answer, disappointingly but not surprisingly, is "only imperfectly." Although there is an economic basis for expecting that on average the accounting costs of fixed facilities will approximate opportunity costs, the approximation is only that. It should hold on average but need not be close at any particular moment. On the other hand, allocating the accounting costs of these facilities ${ }^{96}$ does provide a better approximation of the opportunity costs of their use than we get by assuming they are always equal to zero, which is what occurs when we apply a variable-factors-only approach to calculating incremental cost.

A profit-maximizing firm will employ each productive input at a level such that the value of the marginal product of the input is equal to its price. Use of inputs that are completely variable even in the short run should tend toward this level, even as demand or input prices fluctuate. After all, these variable inputs are variable precisely because they are purchased in the market period after period. For these inputs, then, opportunity cost equals or at least closely approximates their prices at all times.

The inputs that most concern us here are those that are fixed in the short run. For example, some assets, like buildings or certain kinds of specialized equipment, simply cannot be acquired quickly or resold readily without substantial losses. Personnel who are specialized or who must acquire substantial firm-specific skills to perform their jobs may be costly to recruit and train and are therefore not hired or fired in response to shortrun fluctuations. People and things may also have to be purchased in significant "lumps." Certain kinds of plants or equipment are efficient only on a large scale. Analogously, people may be ineffective, or at least inefficient, if they are employed for less than full time or less than a long time.

Nevertheless, these fixed factors of production are subject to maximization principles. In times of high demand, they may have marginal products that are greater than their prices; in times of low demand, they may have marginal products that are less than their prices. Yet maximization principles dictate that that on average, such inputs yield products that, at the margin, are worth their cost.

96. The exact accounting cost of durable facilities is not a simple matter either. Where these facilities are leased, the accounting costs are simple enough, and they will be an appropriate allocation of the periodic lease payment. Such payments are generally fixed, at least for some period of time, and are likely to be recognized as unvarying in litigation. For assets that are owned, the economic user cost of capital is the firm's opportunity cost of capital and depreciation. Accounting practice will recognize the costs of durable fixed facilities (for example, buildings) as depreciation and, in some cases, interest payments on associated debt. 
If, in a particular firm, some fixed factor is persistently worth more than it costs, the firm will increase its profits by increasing its use of that factor. Alternatively-and this is what matters for our cost allocation problem-if a fixed factor regularly yields a marginal product that is worth less than the price of the factor, the firm will increase its profits by decreasing its employment of that factor. There are various avenues for adjustment, such as depreciation without replacement, personnel attrition, or sale or rental of properties. The required marginal equalities are not put right instantly or continuously, as might be approximately the case for freely variable inputs. This does not, however, mean that the use of socalled fixed inputs is tethered permanently away from optimal levels.

What this means is that the accountants are on to something. The implication of the foregoing is that the opportunity cost of incremental uses of inputs that are fixed in the short run will be, on average, about equal to their market prices. Because we can rely on persistent profit-maximizing behavior, the accounting costs of these inputs are a defensible proxy for the values forgone by their use. That is to say, their price is a proxy for the expected opportunity cost of their use in production. This is the economic defense for the full absorption rule.

But even if we accept that accounting cost is an appropriate proxy for opportunity cost, we are left with the question of why we would adopt a proxy at all rather than the real thing. There are at least two answers. First, a proportional allocation of fixed overheads avoids the Herculean task of identifying each unit of each input that is used in the infringing activity and the next step of determining the value of the forgone alternative use of that specific input on each specific occasion that it was used. Such a task is difficult enough, but necessary, for the actual decision makers at the time that decisions are made. It will be much more difficult for outsiders making an evaluation well after the fact. Some courts have commented on the use of proportional allocation rules or other approximations, endorsing them as necessary sacrifices of detail in favor of feasibility. ${ }^{97}$

Second, the opportunity cost of using a fixed factor is typically unobservable. Such a cost is the value of the thing forgone. It is not just unmeasured; it is unseen. For the courts to attempt to measure the value of specific forgone activities would move litigants into a world of stark speculation. The full absorption rule relies instead on the expectation that

97. See Sheldon I, 106 F.2d at 54; see also Kamar Int'l, Inc. v. Russ Berrie \& Co., 752 F.2d 1326, 1333 (9th Cir. 1984) (citing Sheldon I, 106 F.2d at 54); Hamil Am., Inc. v. GFI, 193 F.3d 92, 105 (2d Cir. 1999) ("Once a sufficient nexus is shown between a category of overhead and the production or sale of the infringing product, a court need not scrutinize for inclusion or exclusion particular items within the overhead category."). 
a firm's optimizing behavior adjusts the use of fixed inputs so that they are, at the margin, worth their cost. That is to say, economic theory holds that a profit-maximizing firm adjusts the presence of fixed factors so that the opportunity cost of using them (something that we cannot observe) is equal-only approximately and only on average-to the cost of these inputs (which is observable).

\section{Reconciling Full Absorption with Management Theory}

As noted supra, Koelemay reports that the incremental rule is "consistent with modern business school management theory." $98 \mathrm{He}$ is right that business schools teach incremental reasoning; it is taught in both managerial economics courses and in accounting as contribution analysis. ${ }^{99}$ Further, Koelemay's suggestion that the incremental rule is in line with contemporary thinking is not off target. Explicit endorsement of the incremental rule in case law is a relatively recent phenomenon.

Furthermore, economists are not misguided in teaching students to make decisions by comparing the incremental costs of an action with the incremental benefits. The difference between the two is the gain that is obtained as a consequence of the action being considered. That much is fundamental and correct. But there is a problem with drawing a legal rule from this decision-making principle in economics, namely, that the comparisons that are contemplated in teaching exercises are always highly conditioned - based on assumptions that would be specific to a situation at a particular firm and at a particular time. The basic logic of incrementalism remains correct as we consider a firm's profits from an infringement. But the problem with applying this logic in litigation is that the conditioning assumptions generally do not hold, seldom hold for long, and typically pertain to conditions that cannot be observed by outsiders.

A simple and representative teaching example illustrates the problem: ${ }^{100}$

98. See supra text accompanying note 88 .

99. Evidence of incremental thinking can be found in virtually any economics textbook. For a clear exposition of the basic ideas, see STEVEN LANDSBURG, PRICE THEORY AND APPLICATIONS ch. 5 (2004). It is widely taught in managerial economics classes, including my own. My teaching on this is in an expository essay. See generally Stephen E. Margolis, Cost Concepts for Managerial Decision Making (2000), http://www4.ncsu. edu/ margolis/COST\%20CONCEPTS.doc.

100. This problem is a simplification of a question I have used on an examination in an MBA course in managerial economics. Its basic structure is common. See generally Evan J. Douglas, Managerial Economics: ANAL ysis AND Strategy 303-06 (4th ed. 1992), but in particular question 7-3. 
Newton Electronics sells set-top boxes to cable television operators. Newton has been selling 350,000 boxes a year in transactions that do not involve any long term contracts. They expect that they would continue to sell to their regular customers at this rate. They sell these boxes for $\$ 80$. Newton's costs of making 350,000 of these units are as follows.

Fixed Overhead

Variable Overhead

Direct Labor

Direct Materials
$\$ 16,100,000$

$1,750,000$

$2,800,000$

$4,200,000$

Variable costs are constant up to capacity, which is 500,000 units.

A potential new customer, Minnowvision, has offered to buy 100,000 boxes at $\$ 55$ per box. Should Newton take this offer?

For the current output, the average total cost (that is, the total of all the items shown divided by the current output) is $\$ 71$. To get the correct answer, the student is required to consider the incremental costs, not the average cost, and to notice that the fixed overhead is not a variable cost. The average variable cost, equal to the sum of the bottom three cost items divided by 350,000 , is only $\$ 25$. There is money to be made by selling these boxes at $\$ 55$.

When examples like this are presented in class to MBA students, the most sophisticated ones recognize the game we are playing and come quickly to the answer that the question is designed to elicit. But other smart (and perhaps more experienced) students are unsettled by the assumptions implicit in the question. Would these "new" sales displace sales that the firm was already making? Why doesn't the firm try to solicit other business at $\$ 80$ or something less before they accept $\$ 55$ ? How does the firm know that their current customers won't want more boxes than they have been buying? Is there any likelihood that some other cable television provider will come along with a better offer? And so on.

These are reasonable questions, and they are the questions that should occur to real managers making real decisions. In fact, when students do not raise these objections to the question as stated, I usually prompt them with something like this: "Suppose you really were the manager facing this decision. What concerns would you have? What possibilities would you actually take into account?" Freed from the artifice of the problem, they come up with all of the appropriate additional concerns. Recognizing the necessarily contrived nature of teaching examples constructed to teach incremental comparison, our teaching examples usually include a statement like this: "Assume that nothing else is affected by this decision." 
This is not to say that basic incremental logic is incorrect or inappropriate for management courses. In fact, managers should consider specific situations in detail and compare incremental gains with incremental costs. The manager of our hypothetical electronics plant probably would understand that her average cost is $\$ 71$ at the current output. But she would be ill served if that were the only cost number she kept in her head. If her only accounting information were based on the full absorption modelaverage total cost - she would turn down this business, which in important instances would be a mistake. But a real manager would also consider what options she would be giving up by accepting this business. That is a part of real business decision making, and one that will generally be invisible to the court.

In examples like the one shown supra, with their explicit restrictions, incremental reasoning leads to profit maximizing and socially efficient decisions. But for managers to decide correctly, they must engage in hypothetical deductive reasoning: If I make these assumptions about my future opportunities, what is the consequence of a particular action? This reasoning is the discrete echo of what we do when we evaluate a partial derivative, or equivalently, when we consider marginal revenue and marginal cost. These are appropriate intellectual steps for making decisions, but the incremental profit that results is an intellectual construct, the result of particular assumptions that the manager chooses to make. It cannot be observed simply by looking at accounting data.

This argument would seem to deny the possibility of any reasonable measurement of incremental profits. Indeed it is one more argument against expecting an exact measure. But measurement in litigation will have to rely on some appropriate proxy for the opportunity cost of fixed factors, and a defendable approximation is available-allocation of fixed costs. While this proxy cannot perfectly recover the opportunity costs associated with the use of fixed factors in a particular instance, it provides a better approximation than ignoring them altogether.

\section{A Brief Comment on Capacity}

The economic argument for the use of full absorption rests on the understanding that where there are fixed factors of production, a commercial activity occurs at a cost of giving up other valuable activities. That understanding raises the issue of capacity. 


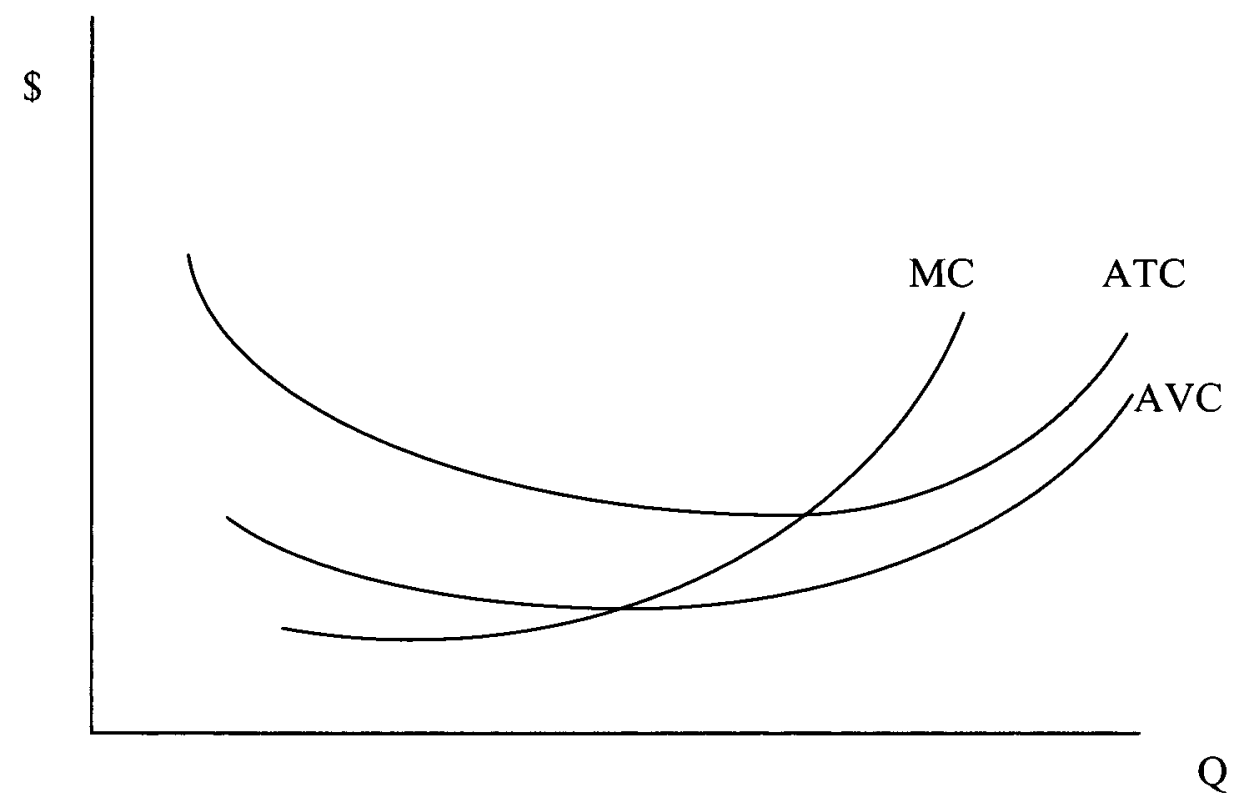

Figure 1: Short Run Cost Curves

Figure 1 is a completely conventional representation of a firm's shortrun cost curves, as found in most any microeconomics textbook. In the diagram, the upward-sloping marginal cost curve (MC) illustrates the influence of a fixed factor. At low outputs, additional units of output are available at low cost; that is, marginal cost is small. At some point, however, the capacity constraint begins to bind. Because the fixed factor or factors become "crowded" at sufficiently large levels of output, it becomes more difficult to produce additional units, which is to say that marginal cost rises. At high levels of output, relative to the range shown, the marginal cost curve becomes quite steep, indicating that additional units of output are produced with considerable difficulty as the limitations imposed by fixed factors become severe.

The other two curves are average variable cost (AVC) and average total cost (ATC). These are "dragged around" by marginal cost. As marginal cost becomes high enough, the average cost of the entire output is increased by additional units of output.

One notion of capacity, and the common meaning of the word, is an absolute limit. The capacity of a pickle jar is reached when it is not possible to stuff another pickle into the jar no matter how hard you try. Similarly, we could consider the capacity of a manufacturing facility to be the level of output at which not a single additional unit of output could be produced at any cost. That notion of capacity, however, is not particularly 
useful because expansion of output would be called off well before such a limit is reached. As that theoretical absolute limit is approached, the cost of additional output would become prohibitive.

A definition of capacity that economists use in many contexts is the quantity at which average total cost is minimized. Certainly it is possible to obtain more units beyond that point, but output beyond that point increases the average cost of output. This "capacity" of a facility is consistent with the idea of design capacity-the intended level of operation. Economists use the phrase "excess capacity" to describe the situation in which output is below the level of output that minimizes average total cost. For outputs larger than that, we speak of insufficient capacity. In full competitive equilibrium, price is forced down to the minimum possible ATC. Producing units of output beyond the quantity that minimizes ATC is not profitable at that equilibrium price. Thus the market confirms this meaning of capacity.

What all this shows is that while it is generally possible to produce additional output, there are nevertheless limitations imposed by fixed inputs. These limitations are experienced as elevated costs. The potential error here is that we might observe the possibility of squeezing out additional output and erroneously draw the conclusion that the capacity constraint does not bind and that there are no opportunity costs of using fixed facilities. Yes, it will be possible to produce one more unit of output, or perhaps many more units of output, but where the firm is at "capacity," as economists use the term, producing that additional unit will be costly and often unprofitable. In the diagram, notice that at capacity, as defined here, marginal cost is equal to the average of all costs (ATC) and not the average of variable costs. That is, we can calculate the incremental cost of output correctly only if we include fixed costs. Conversely, the tempting expedient of computing marginal cost as the average of variable costs is correct only where the firm is operating well below capacity, where again capacity means output at which average cost is minimized, not the absolute theoretical maximum output.

\section{E. Case Law: Another Look}

The opportunity cost perspective is not always ignored in case law. The opinion of the Sixth Circuit Court of Appeals in Schnadig Corp. v. Gaines Manufacturing Co., Inc. ${ }^{101}$ articulates an incremental view with specific consideration of whether fixed facilities had alternative uses. This

101. See Schnadig Corp. v. Gaines Mfg. Co., Inc., 620 F.2d 1166, 1171-76 (6th Cir. 1980). 
design patent case reached the court of appeals on the issue, among other things, of allocating fixed costs in determining the infringer's profits. ${ }^{102}$ The parties had agreed to the amount that they considered fixed cost, and the district court had allowed approximately two-thirds of fixed costs to be counted in the profits calculation. The plaintiff objected to any deduction of fixed costs.

The Schnadig court, with enviable brevity, sums up the status of this controversy in both law and economics: "Neither case law nor logic provides a clear rule for the proper treatment of fixed expense in computing an award of profits." 103 The court provides admirably clear statements in support of each of the two approaches and then offers this resolution:

The ideal approach to resolving the conflicting considerations present here would be to ascertain whether without the infringement the defendant could have employed the facilities which were devoted to the infringing production in a manner which would have covered the fixed costs at issue. If no alternative use were available, the fixed costs sought to be allocated against the profits from the infringement would have been borne by the defendant's non-infringing production, and a recovery of these costs would in effect reduce the cost of his other production, resulting in a net gain from the infringement. ${ }^{104}$

The court also recognizes the impracticality of implementing this "ideal" approach fully: "[W]e recognize that it will be difficult for the parties to show and the judge to determine what might have been." 105 The parties in the case had not addressed the issue of alternatives, but the court ultimately finds support for the district court's allocation of a substantial portion of the fixed costs in the fact that the defendant generally managed to keep its facilities busy: "[T]he record indicates that Gaines' business was quite successful and growing rapidly during the period in question." 106

The definition of "profit" in design patent infringement was a matter of first impression in the Sixth Circuit, ${ }^{107}$ but the Schnadig court did draw

102. Owners of design patents can be awarded the profits of an infringer. 35 U.S.C. $\S 289(2000)$. In this regard, design patents are like copyright and unlike utility patents.

103. Schnadig, 620 F.2d at 1172.

104. Id.

105. Id.

106. Id.

107. Id. at 1168 . 
on Levin, ${ }^{108}$ a patent case in the Eighth Circuit, noting that prior to 1946 a patentee could recover an infringer's profits. Against the plaintiff's appeal that all overhead be disallowed, the Levin court affirms the lower court in allowing an allocation of some overhead costs, those costs that had a direct connection to the manufacture and sale of the infringing goods:

It often happens that overhead expenses are applicable to and should be spread over the entire business but where a business is established and in operation and another line is taken on without an increase in overhead expenses it is just to the patentee that the actual situation be applied and none of such overhead be charged as an expense of the added line except as it participated in manufacture or sale of the infringing article. ${ }^{109}$

After noting with approval that the statute has "gone quite far to take away from [the] infringer every vestige of gain through his wrongful act," the Levin court then cautions:

On the other hand, this theory of not allowing overhead where it has not been increased is of narrow application and not to be extended for it is manifest that every item of expense which should properly be included in the manufacture and sale of the infringing article should be so included in ascertaining the real profit thereon. ${ }^{110}$

Thus, Levin sets the table for both the "assists in the production" rule in Sheldon and the opportunity-cost-based reasoning in Schnadig.

By limiting deductibility to those overhead categories that "assist in production," Judge Hand's departure in Sheldon from a full absorption rule is a nod in the direction of an incremental opportunity cost rule. Where overhead items have no association with the production of the infringing goods, it is reasonable to think that there is no opportunity forgone with regard to limitations imposed by that fixed input. But that explanation can be pushed too far. Typically, the available accounting data presents cost information for broad aggregates of inputs, and the courts have generally stopped short of an input-by-input inquiry into the production process. Thus the accuracy contributed by the "assist in production" rule is limited by the aggregation imposed by the accounting practices of the infringer.

108. See Schnadig, 620 F.2d at 1172-73 (discussing Levin Bros. v. Davis Mfg. Co., 72 F.2d 163 (8th Cir. 1934)).

109. Levin, 72 F.2d at 166.

110. Id. 


\section{LAW AND ECONOMICS II: SHELDON AS AN INCREMENTAL OPPORTUNITY COST RULE}

The claim of the previous Part is that the full absorption rule articulated in Sheldon, which calls for allocation of the costs of overheads that are involved in infringing production, is grounded as an incremental rule that uses the accounting costs of fixed inputs as a proxy for the opportunity cost of using those inputs in an infringing activity. Thus, the full absorption rule (or near full absorption rule) more properly reflects the economic logic of an incremental rule than the variable-costs-only incremental alternative. Moreover, this understanding of the Sheldon rule is anticipated in Levin, its precursor, and further developed in Schnadig.

This understanding of Sheldon prompts several questions. First, what does this rule actually do? That is, in what sense does it capture the defendant's gain from infringement? Second, if we are to understand the Sheldon rule as a satisfactory proxy for profit, how does it fall short of an exact measure, and why should we be satisfied with it? And third, are there further implications for the treatment of overheads that follow from this understanding?

\section{A. What Does Sheldon Do?}

A simple answer to this question is that the Sheldon rule captures a share of the accounting profits of the firm, in proportion to the share of the infringing activity of the firm's overall activity and adjusted for the advantage conferred by the infringed property. The details behind this simple answer, which are not so simple, follow in this Section.

It is tempting to suppose that a full absorption rule necessarily yields a profit rate (profits/revenues) for the infringing activity that is identical to the profit rate for the business unit as a whole. After all, if all costs are allocated to products in proportion to sales, then costs as a percentage of sales will be uniform across products, and therefore, so will profits. This will not be the case, however, so long as the direct costs of a product can be determined (as is often the case) and the infringed copyright or trademark actually protects something that is valuable.

Where the creative contribution that is protected by copyright actually adds something to the value of the product, the direct costs that are associated with the product will typically be a smaller share of the price of the product than the corresponding share for the firm's generic production. That is, the contribution of intellectual property will be manifest as an increased willingness to pay for the protected item as compared to the firm's unprotected or generic goods of equivalent cost. An additional use of the intellectual property itself does not add to direct costs. Therefore, goods 
that embody valuable intellectual property will have margins on variable costs that are greater than the margins on variable costs of unprotected goods. Thus, even when the overhead "loads" are added to cost, protected goods will show greater profit margins.

Taking a very simple example, suppose that in a particular firm overheads are $80 \%$ of direct costs. Further, suppose that for unprotected goods that the firm produces, direct costs constitute $50 \%$ of revenues, while the equivalent figure for protected goods is $25 \%$. (Equivalently, the price of unprotected goods is twice the direct cost per unit, while the price of protected goods is four times the direct cost per unit.) In such a case, the accounting profit for unprotected goods would be $10 \%$, while the accounting profit for protected goods would be $55 \% .{ }^{111}$ In this example, the recovery available to the plaintiff under a full absorption rule, absent any specific punitive measures, would be $55 \%$ of the revenues from the infringing product. ${ }^{12}$

Notice that in this simple illustration, the apparent contribution of the intellectual property is $45 \%$ of revenues, which is the difference between the profitability of generic production $(10 \%)$ and the protected production $(55 \%)$. What happens then, even with the full absorption rule, which I have argued is approximately an opportunity cost rule, is that the plaintiff captures both the contribution of the intellectual property and the margin ordinarily offered by the firm's unprotected or generic production.

Is the $55 \%$ profit? By one definition, it would certainly be accounting profit - profits under a full absorption rule. Notice, however, that even this measure, which reduces profits in comparison to the incremental method by allowing a deduction for overheads, is greater than the stipulated contribution of the intellectual property, $45 \%$. Is there any foundation, either in law or in economics, for using this measure of profits as the basis for a monetary award?

Further, what is the source of the difference between this profit, as measured under a full absorption rule, and the contribution of the intellec-

111. Elaborating, for generic production, costs as percent of revenue are $50 \%$ (direct costs) plus $40 \%$ (overhead), equaling $90 \%$ of revenue. By the assumption above, overhead is calculated as $80 \%$ of $50 \%$, which is $40 \%$. For protected production, costs as a percent of revenue are $25 \%$ (direct costs) plus $20 \%$ (overhead), equaling $45 \%$ of revenue. By the assumption above, overhead is calculated as $80 \%$ of $25 \%$, which is $20 \%$. Accounting profits as a fraction of revenues are thus $10 \%$ and $55 \%$ for generic and protected production respectively.

112. Under an incremental rule, the defendant's profits would be $75 \%$ of revenues; the $55 \%$ computed under the full absorption rule, plus the $20 \%$ of overhead that would be excluded. 
tual property? It is, of course (and becoming almost completely circular), the margin that the firm earns on its generic production. But why do these profits appear in the accounting even after all of the overheads have been "absorbed"?

The answer is that this return-the $10 \%$-is the return to attributes of the firm that are valuable and that are not recognized in the firm's accounting. These could be common assets that the firm owns-equity in buildings or equipment, for example - that add value to the firm's output. Even in competition, the returns to these assets are not forced to zero since other firms must also acquire the services of these types of assets. We would not consider the returns to these assets to be economic profits, but they are accounting profits. In full competitive equilibrium, these are the normal returns to investment.

But these accounting profits can also reflect other things about the firm that allow it to earn accounting profits. The firm could own other intellectual property, or enjoy some degree of monopoly power by virtue of unique capabilities that are not readily imitated. The firm might have simply assembled a group of employees that are particularly effective at working together, or have developed ways of doing business that provide cost advantages. These are all attributes of the firm that are advantages in the obvious sense that the firm is better off with them than without them. If it were possible to identify each of these attributes and to account for their contributions to profits as the returns to those assets, we would account for all of the firm's accounting profits as returns to assets, not as "profits." ${ }^{113}$ It is in this sense that Harold Demsetz, in another context, argues that what we calculate as profits is a result of what we exclude, either by choice, necessity, or omission, from explicit accounting. ${ }^{114}$

This perspective would lead us to interpret profits due to infringement as the contribution of the intellectual property (the $45 \%$ in the numerical example supra, and not the $55 \%$ ). Everything else that the plaintiff would

113. Interestingly, in the standard pedagogy of perfect competition in introductory economics classes, accounting profits are explained as normal returns on investment. Further, if a firm in competition differs from the marginal firm in ways that yield greater accounting profit, the extra profits are explained as returns on the firm's unique assets, so that the zero-profit result can be maintained. But typically this reasoning is not usually extended to apply outside perfect competition, although it applies just as well. An important exception is Demsetz, see infra note 114.

114. Harold Demsetz, Two SyStems of Belief About Monopoly in INdUSTRIal CONCENTRATION: THE NEW LEARNING 164-84 (1974). Demsetz discusses profits across industries in this paper, arguing that our election to interpret differences in profits as differences in monopoly power is essentially arbitrary. 
claim (the additional $10 \%$ ) is really a return to other assets that the defendant owns.

It could be argued, then, that if we are taking full account of opportunity costs, we should make the additional assumption that in the absence of the infringement, the defendant would undertake some alternative activity in its place that would be of similar scale and just as profitable as his other noninfringing production. That assumption would recognize that there are assets of the firm that are not explicitly accounted for that also have opportunity costs. The defendant would keep the $10 \%$.

But this is not what the law does. Consider again the simple case where an enterprise comes into existence for the sole purpose of infringement, produces as its only output an infringing good, leases all its capital goods, and then goes out of business, so that all costs are incremental to the infringement and no issues of overhead are raised. In that case, an "accounting of the profits" would yield all of the accounting profits to the plaintiff. The entire existence of the firm is the infringement, and the entire proceeds of the firm would likely be awarded to the intellectual property owner. The defendant would not be allowed to retain the earnings that might have been available in some similar but noninfringing entrepreneurial activity. Further, the law distinguishes in places between damages, which are often treated as the reasonable royalty that is unpaid as a result of the infringement, and the profits of infringement. Can the claim that Sheldon is an incremental opportunity cost rule be reconciled with the exclusion of some opportunity costs? That question is taken up in the next Section.

\section{B. Russ Berrie's ${ }^{115}$ Sense of Style: Reconciling Sheldon with the Exclusion of Some Opportunity Costs}

Suppose a firm produces a variety of goods, each involving some creative element, and that for most of its production, the firm applies its own creative capability. Perhaps by tradition and experience, the firm can produce goods that reflect a style or feel or tone or sense of humor that the public recognizes and values. Such a capability would be an asset that could earn revenues that are consistently above the sum of all of its accounting costs. Now suppose the firm infringes, copying a good produced

115. It could have been Willie, and Waylon and Russ. For those who may be unfamiliar with Mr. Berrie, he is something of an intellectual property outlaw, a modern day Robin Hood bringing low priced toys, gift items, and greeting cards to the frugal and less advantaged. Unfortunately, several of Mr. Berrie's well-intended efforts trespassed on others' trademarks and copyrights. See Roulo v. Russ Berrie \& Co., 886 F.2d 931 (7th Cir. 1989); Kamar Int'l, Inc. v. Russ Berrie \& Co., 752 F.2d 1326 (9th Cir. 1984). 
by another firm, or at least appropriating a creative vision developed elsewhere. Is there any basis for assuming that the firm's customary contribution to its products is present in the infringed products? Or in other words, is there any basis for splitting the profits between the contribution of the infringed property and the contribution of the firm's own special attributes? Perhaps the firm brought its usual sense of style, or entrepreneurial insight, or market savvy, to the infringing activity, but perhaps not. Perhaps instead the firm infringed because it was fresh out of ideas, tired and jetlagged from a trip to China. ${ }^{16}$ There is no reliable way to separate the two components. The intangible contributions of the firm and the contribution of the intellectual property have been mixed and cannot be reliably separated. Accordingly, measurement problems are one justification for including the intangible contributions of the firm in profits under the Sheldon rule. Judge Hand provides another justification in Sheldon:

Indeed a constructive trustee, who consciously misappropriates the property of another, is often refused allowance even of his actual expenses (Restatement of Restitution Sec. 158d) and although this harsh rule, which would charge the defendants with the whole gross receipts, has been softened, a plagiarist may not charge for his labor in exploiting what he has taken. A fortiori he should not be allowed for the currency which his reputation may have given to the combined product. ${ }^{117}$

A key phrase here is "A plagiarist may not charge for his labor." The ordinary returns to the unpriced attributes of the firm-the missing $10 \%$ in the numerical example-are the normal earnings of the plagiarizing firm. While we do not think of these returns as a charge for the firm's labor, they are the returns to what the firm owns, the returns to the property that the firm constitutes. These are the earnings of the plagiarist, returns to the "property" that has been mixed, by the action of the infringer, with the property of the copyright owner.

Other aspects of the quoted passage are also germane. The infringer becomes a constructive trustee, who has, by mixing his property with that of an unwilling copyright owner, placed his own property at risk. The value of the contribution of the property of the infringer is not explicitly

116. In New Line Cinema Corp. v. Russ Berrie \& Co., 161 F. Supp. 2 d 293 (S.D.N.Y. 2001), Mr. Berrie's account of his shopping trips to China are entertaining and quoted at length in the court's opinion. Although his account conveys an atmosphere of some rush and chaos on these trips, there is nothing in the record about being jetlagged or tired.

117. Sheldon I, 106 F.2d at 51. This passage is cited frequently. See Kamar, 752 F.2d at 1331; ZZ Top v. Chrysler Corp., 70 F. Supp. 2d 1167, 1169 (W.D. Wash. 1999). 
accounted for, and is perhaps unmeasurable. Awarding the entire margin to the infringed party-the $55 \%$ in the example supra-is consistent with the general principle that one who carelessly or deliberately mixes his property with another's will give up the benefit of the doubt when the property is separated. Again in Sheldon: "the defendants must be content to accept much of the embarrassment resulting from mingling the plaintiffs' property with their own."118

Just before the passage cited supra, Judge Hand writes: "On the other hand, the defendants may not count the effect of their standing and reputation in the industry; perhaps the most important factor of all, after the [movie] stars." 119 And then, regarding deductible costs, he writes, "It follows that they [the defendants] can be credited only such factors as they bought and paid for; the actors, the scenery, the producers, the directors and the general overhead." ${ }^{20}$ Clearly, the court is distinguishing between the costs that can be accounted for as expenditures-including expenditures on overheads - and those that cannot.

The Sheldon rule does award the plaintiff a slice of the defendant's profits; the contribution of the intellectual property and a proportionate share of the overall profit of the firm. In that regard, it does manage to provide, for the multiproduct, multi-period enterprise, a measure of profits that is congruent to the measured profits of a single-product, single-period enterprise that comes into existence to produce the infringing goods and leases any necessary capital goods. There is no reason to think that the former should be treated more harshly than the latter in an infringement action.

\section{Exceptions}

This Article does not propose a new rule but rather offers an economic explanation of the Sheldon rule--a rule that on the surface might seem to run contrary to economic reasoning. But the opportunity cost justification for allocating overheads does suggest certain exceptions to a full absorption rule. These would include instances in which the infringement replaces the firm's own creative workers, and instances in which excess capacity can be established. Further, the inclination to disallow overhead deductions where the infringement is willful can be shown to be consistent with an opportunity cost justification for allowing deductions of overheads. Interestingly, some of these exceptions will conform to Sheldon's instruction that "'Overhead' which does not assist in the production of the

118. Sheldon I, 106 F.2d at 51 .

119. Id. at 50.

120. Id. at 51 . 
infringement should not be credited to the infringer; that which does should be; it is a question of fact in all cases."

Some firms that deal primarily in goods that embody intellectual property will have employees and even entire divisions that produce intellectual properties. For example, a firm that produces software products will have employees who develop the software. The wages and support expenses for these employees are likely to appear as research and development expense, which is treated as overhead. Where a software firm copies software that another firm has developed, and consequently avoids using its own development staff, there are no lost opportunities in software development. In this circumstance, it would not be proper to allocate the costs of the software development staff, and the "does not assist" provision of the Sheldon rule would appropriately exclude any allocation of the cost of the development staff.

Of course, in real cases, the facts may not be so tidy. The software staff, which customarily designs entire products, might be involved with the infringing production, but only to integrate it with the infringer's other products. In such a case, the Sheldon rule might lead the court to allow a full allocation of the cost of software development, yet the contributions (and hence the opportunity costs) of the software development staff would be disproportionately small. Similar examples can be constructed: an infringing movie production company might employ scriptwriters for its noninfringing movies; an infringing toy manufacturer might employ toy designers to make noninfringing toys; an infringing map publisher might employ cartographers; or an infringing newspaper publisher might employ reporters. In short, the costs of the "creative works department" of a firm that has infringed a creative work should be subject to particular scrutiny.

As noted supra, some courts disallow the allocation of overheads where the infringement is found to be willful. But there is nothing inherent in generally accepted accounting principles that would suggest that profits should be defined differently when the principals are behaving badly. Accordingly, it would seem that the practice of many courts of disallowing overheads in the presence of willfulness can only be interpreted as punitive. Given that the profits measure is not supposed to constitute punishment, and that there are explicit punitive measures available to the court, the linking of willfulness and overheads seems to sneak in an extra layer of punishment.

In contrast, the opportunity cost explanation does provide some justification for not allowing willful infringers to deduct overhead. As discussed

121. Id. at 54 . 
supra, ${ }^{122}$ willfulness is not merely conscious copying, but copying in the face of clear and credible notification that the copying is infringement. That an infringer would infringe even in the face of clear notice suggests that the returns to the infringement are significantly different from the returns available in the firm's next best alternative. In such a case, willfulness suggests that the firm had no feasible alternative that would make use of its fixed facilities. Or, to view this from the opposite side, a firm that has good alternative opportunities, so that the infringing production does not offer significantly larger returns, would be quick to switch to noninfringing production in the face of clear evidence that their production will lead to legal liability. By this argument, we would expect that a conventional accounting of profits, which would allocate all overheads, might understate the actual advantages of infringement. This provides some justification for excluding overheads, or at least subjecting them to greater scrutiny, where infringement has been decidedly willful.

In Sheldon, the court does find willfulness, but nevertheless allows a fairly extensive allocation of overheads. Still, the Sheldon court does limit deductions to "only such factors that were bought and paid for" in light of its finding of willfulness. ${ }^{123}$

Finally, the opportunity cost explanation suggests that the issue of capacity is a factual matter. The opportunity cost justification of the Sheldon rule imbeds a presumption that use of a firm's facilities has an opportunity cost. This is a rebuttable presumption. If a firm is chronically operating below capacity, the court might properly decline to allocate overheads. If, for example, the infringement is the basis for reopening long-shuttered facilities, the costs associated with those facilities might well be excluded.

\section{CONCLUSION}

In a successful infringement action, the owner of an infringed trademark or copyright is entitled to the defendant's profits. The corresponding statutes do not define profits, but a reasonable interpretation of the language of the law as well as economic reasoning supports the view that profits should be defined and computed to be the gain from infringing.

The gain from infringing is the incremental revenue less the incremental cost. That language has, in some courts, been taken to support a rule that allows deductions only for costs associated with variable inputs. The argument presented here is that such a legal rule is a misconstruction of the economic notion of incremental cost. Infringing production that

122. See supra text accompanying note 69.

123. Sheldon I, $106 \mathrm{~F} .2 \mathrm{~d}$ at 51 . 
uses fixed facilities will typically impose costs in the form of lost opportunities for other profitable production. While explicit consideration of the values of those lost opportunities would be highly speculative and ultimately infeasible, profit-seeking behavior will imply that, on average, the marginal values of fixed facilities will be equal to their costs. This creates a presumption in favor of allocating the costs of fixed facilities. This contrasts with an incremental rule that bars all accounting cost items that are not altered by the infringing activity.

Defining the cost of infringement as incremental opportunity cost reconciles a full absorption rule with economists' incrementalism. This reasoning is also anticipated in some of the precedents for a full absorption rule, most notably in Sheldon and Levin, and most explicitly in Schnadig.

The treatment of overheads matters. Overheads are typically a large share of total cost. Disallowing overheads can easily increase calculated profits by an order of magnitude. An incremental rule therefore may routinely result in much larger awards to infringed parties than a full absorption rule. The possibility of larger awards will result in more litigation, more precaution against inadvertent infringement, and greater business risk. Risk-averse fair-users may be deterred by even a very remote possibility that their use would be deemed unfair. Absent a common view on the allocation of overheads, the unsettled nature of the legal rules also increases the uncertainty of outcomes in litigation, discouraging settlement. 
BERKELEY TECHNOLOGY LAW JOURNAL 